\title{
The initiation of modern soft and hard Snowball Earth climates in CCSM4
}

\author{
J. Yang ${ }^{1, *}$, W. R. Peltier ${ }^{2}$, and Y. Hu ${ }^{1}$ \\ ${ }^{1}$ Laboratory for Climate and Ocean-Atmosphere Studies, Department of Atmospheric and Oceanic Sciences, \\ School of Physics, Peking University, Beijing, China \\ ${ }^{2}$ Department of Physics, University of Toronto, Toronto, Ontario, Canada \\ * formerly at: Department of Physics, University of Toronto, Toronto, Ontario, Canada
}

Correspondence to: J. Yang (junyang @ pku.edu.cn)

Received: 11 November 2011 - Published in Clim. Past Discuss.: 2 January 2012

Revised: 2 May 2012 - Accepted: 2 May 2012 - Published: 16 May 2012

\begin{abstract}
Geochemical and geological evidence has suggested that several global-scale glaciation events occurred during the Neoproterozoic Era in the interval from 750580 million years ago. The initiation of these glaciations is thought to have been a consequence of the combined influence of a low level of atmospheric carbon dioxide concentration and an approximately $6 \%$ weakening of solar luminosity. The latest version of the Community Climate System Model (CCSM4) is employed herein to explore the detailed combination of forcings required to trigger such extreme glaciation conditions under present-day circumstances of geography and topography. It is found that runaway glaciation occurs in the model under the following conditions: (1) an $8-9 \%$ reduction in solar radiation with $286 \mathrm{ppmv} \mathrm{CO}_{2}$ or (2) a $6 \%$ reduction in solar radiation with $70-100 \mathrm{ppmv} \mathrm{CO}_{2}$. These thresholds are moderately different from those found to be characteristic of the previously employd CCSM3 model reported recently in Yang et al. (2012a,b), for which the respective critical points corresponded to a $10-10.5 \%$ reduction in solar radiation with $286 \mathrm{ppmv} \mathrm{CO}_{2}$ or a $6 \%$ reduction in solar radiation with $17.5-20 \mathrm{ppmv} \mathrm{CO}_{2}$. The most important reason for these differences is that the sea ice/snow albedo parameterization employed in CCSM4 is believed to be more realistic than that in CCSM3. Differences in cloud radiative forcings and ocean and atmosphere heat transports also influence the bifurcation points. These results are potentially very important, as they are to serve as control on further calculations which will be devoted to an investigation of the impact of continental configuration.
\end{abstract}

We demonstrate that there exist "soft Snowball" Earth states, in which the fractional sea ice coverage reaches approximately $60-65 \%$, land masses in low latitudes are covered by perennial snow, and runaway glaciation does not develop. This is consistent with our previous results based upon CCSM3. Although our results cannot exclude the possibility of a "hard Snowball" solution, it is suggested that a "soft Snowball" solution for the Neoproterozoic remains entirely plausible.

\section{Introduction}

Based on observations of glacial deposits on the continents at low latitudes, the associated extreme carbon isotope fluctuations, the existence of banded iron formations (BIFs) and post-glacial cap carbonates in glacial deposits of the Neoproterozoic era, it is generally thought that two significant and global-scale glaciations occurred at $\sim 716 \mathrm{Ma}$ and at $\sim 635 \mathrm{Ma}$, during which land-based ice sheets reached deep into tropical latitudes. However, it is still disputed as to whether the entire ocean was covered by thick sea ice, the so-called "Snowball" or "hard Snowball" Earth hypothesis (Kirschvink, 1992; Hoffman et al., 1998; Hoffman and Schrag, 2002), or whether tropical open-water oceans coexisted with low-latitude continental ice sheets, the so-called "Slushball" or "soft Snowball" Earth hypothesis (Hyde et al., 2000; Peltier et al., 2007; Allen and Etienne, 2008). Aside from these major variations upon what is generally agreed to have been extreme glacial conditions, additional suggestions 
as to the nature of Neoproterozoic climate have included a state in which the global ocean was covered by sea ice, but the tropical sea ice was thin enough to provide suitable refugia to explain the survival of eukaryotic life (Pollard and Kasting, 2005; Warren and Brandt, 2006), and one in which the tropical ocean was covered by sea ice, but the polar regions were ice-free, the "high-obliquity" hypothesis (Williams, 2008, and references therein).

Snowball initiation is a crucial aspect of the debate. Budyko (1969) and Sellers (1969) found, using simple energy balance models (EBMs), that when sea ice is forced to advance to below approximately $30^{\circ}$ latitude, runaway glaciation would occur, owing to a strong nonlinear ice albedo feedback, and therefore a "soft Snowball" solution with open water continuing to exist at the Equator would be unstable. In some general circulation models, various authors also have found this characteristic to prevail (e.g. Lewis et al., 2007; Voigt and Marotzke, 2010; Voigt et al., 2011). However, in other models, it is found that a state with tropical open-water may be stable even if the sea ice edge reaches as low as $10^{\circ}$ latitude (Chandler and Sohl, 2000; Baum and Crowley, 2001; Pierrehumbert et al., 2011; Abbot et al., 2011; Yang et al., 2012a,b). One of the reasons for the absence of runaway glaciation in these models may be associated with the relatively low sea ice and/or snow albedo employed, which restricts the strength of the albedo feedback (Pierrehumbert et al., 2011; Yang et al., 2012a). For instance, the sea ice albedo in EBM/ice sheet models has been set to be as low as 0.45 (Hyde et al., 2000; Peltier et al., 2004, 2007; Liu and Peltier, 2010, 2011), and the snow albedo in CAM3 and CCSM3 is set to 0.66-0.78 (Pierrehumbert et al., 2011; Abbot et al., 2011; Yang et al., 2012a), both of which are smaller than observations, $0.47-0.52$ for bare sea ice, $0.55-0.66$ for sea glacier and 0.75-0.87 for snow (Perovich, 1996; Warren et al., 2002; Warren and Brandt, 2006). As the sea ice and/or snow albedo increases, it will clearly be easier to enter a globally ice-covered state (Lewis et al., 2003; Pierrehumbert et al., 2011; Yang et al., 2012a).

Furthermore, in previous models, the parameterization for sea ice and snow albedo has been overly simplified (Briegleb and Light, 2007; Yang et al., 2012a). The dependencies of surface albedo on the solar zenith angle, snow grain radius, cloud cover and the incidence of melt ponds have been neglected, which have significant influence on temporal and spatial variations of the surface albedo (Wiscombe and Warren, 1980; Perovich et al., 2002). The most recent version of the National Centre for Atmospheric Research (NCAR) model, CCSM4, has taken these influences into account by employing a consistent delta-Eddington multiple scattering scheme for sea ice/snow and a semi-empirical parameterization for melt ponds (Briegleb and Light, 2007; Flocco et al., 2010; Holland et al., 2012). This model has also employed more realistic sea ice/snow albedo than the somewhat low values assumed in CCSM3 (Table 1).
Table 1. Typical albedos for sea ice ( $>1 \mathrm{~m}$ ), sea glacier (compressed snow over ocean), snow and melt pond in CCSM3, CCSM4 (see Briegleb and Light, 2007; Yang et al., 2012a) and observations (see Perovich, 1996; Warren et al., 2002; Warren and Brandt, 2006).

\begin{tabular}{lccc}
\hline Surface type & CCSM3 & CCSM4 & Observation \\
\hline Sea ice & $0.43-0.50$ & $0.61-0.65$ & $0.47-0.52$ \\
Sea glacier & & & $0.55-0.66$ \\
Snow & $0.66-0.78$ & $0.71-0.91$ & $0.75-0.87$ \\
Melt pond & & $0.10-0.52$ & $0.15-0.40$ \\
\hline
\end{tabular}

The primary purpose of this paper is to investigate the initiation of a modern Snowball Earth with CCSM4 as a function of a reduction in solar constant and/or carbon dioxide concentration. We will determine the thresholds for the occurrence of a "hard Snowball" and the conditions for the existence of a "soft Snowball" and compare them with our previous results obtained using CCSM3 (Yang et al., 2012a,b). These comparisons are an important prerequisite for the next step in this new series of analyses of the Snowball Earth hypothesis, in which we will also include the impact of the change in continental configuration, as discussed in Liu and Peltier $(2010,2011)$ in the framework of coupled energy balance-ice sheet models. It is clearly important that the results of such calculations are not biased by the choice of a coupled climate model that improperly shifts the bifurcation points that would exist in the absence of this influence.

\section{Model description and experimental design}

The NCAR Community Climate System Model version 4 (CCSM4) is a fully coupled ocean-atmosphere-land-sea-ice model that may be employed for the simulation of past, present and future climates. A relatively low resolution version suitable for paleoclimate studies, is employed in the present work. The atmosphere component is an atmospheric general circulation model with a spectral Eulerian core and a horizontal grid with a resolution of $3.75^{\circ}$ (Neale et al., 2011). In the vertical the atmosphere has 26 levels from the surface to approximately $2 \mathrm{hPa}$. The land component is the Community Land Model version 4 (CLM4), which uses the same horizontal resolution as the atmosphere component (Lawrence et al., 2011). The ocean component is based on the Parallel Ocean Program version 2 (Smith et al., 2010), which has a horizontal grid consisting of $100 \times 116$ points and a zonal resolution of $3.6^{\circ}$. The meridional resolution is variable with a spacing of approximately $0.9^{\circ}$ around the Equator. There are 60 depth layers in the vertical (vs. 25 depth layers in CCSM3), with a resolution of $10 \mathrm{~m}$ from the surface to $200 \mathrm{~m}$. The sea ice module is the Community Ice Code version 4 (Hunke and Lipscomb, 2008), which employs the same horizontal grid as the ocean module. 
Compared to the previous version CCSM3, CCSM4 includes several significant developments and improvements, including a much improved representation of atmospheric deep convection, a new freeze-dry scheme for polar low clouds, an improved representation for surface runoff and frozen soil, an improved parameterization for near-surface oceanic eddies, new parameterizations for submesoscale mixed layer eddies and ocean overflows, and a new radiative transfer scheme for sea ice/snow (Gent et al., 2011; Shields et al., 2012, and references therein). These changes improve the model representations of the frequency of ENSO variability (Richter and Rasch, 2008; Neale et al., 2008), of polar cloud cover (Vavrus and Waliser, 2008), of the penetration of the North Atlantic meridional overturning circulation (Danabasoglu et al., 2010), of land water storage (Lawrence et al., 2011), and of the Arctic sea ice concentration and its trend (Gent et al., 2011). For example, the ENSO power spectrum in CCSM4 is now comparable to the observed 2-7 yr period (Gent et al., 2011), whereas it is dominated by variability at $\sim 2 \mathrm{yr}$ period in CCSM3 and its precursors (Collins et al., 2006a; Peltier and Solheim, 2004). As a further example, the Antarctic bottom water (AABW) transport in CCSM4 is approximately $8 \mathrm{~Sv}$, which is in much better agreement with observations and much weaker than in CCSM3 ( 16 Sv) (Danabasoglu et al., 2012).

In the first step of the present analyses, we have run the CCSM4 model subject to pre-industrial (PI) forcings: solar constant is set to $1360.89 \mathrm{~W} \mathrm{~m}^{-2}$ and carbon dioxide concentration is set to $286 \mathrm{ppmv}$. To simulate the initiation of the extremely cold climates characteristic of the Neoproterozoic, 9 experiments with different solar constants of $89-100 \%$ of the present-day level $\left(1367.0 \mathrm{~W} \mathrm{~m}^{-2}\right)$, under $286 \mathrm{ppmv} \mathrm{CO}_{2}$ concentration conditions and 16 experiments with different $\mathrm{CO}_{2}$ concentrations of 35-1144 ppmv, under $94 \%$ solar radiation conditions (relative to $1367.0 \mathrm{~W} \mathrm{~m}^{-2}$ ) have been carried out. Other atmospheric greenhouse gases are fixed at pre-industrial levels: $\mathrm{CH}_{4}=805.6 \mathrm{ppbv}, \mathrm{N}_{2} \mathrm{O}=276.7 \mathrm{ppbv}$, and no CFCs. Monthly mean climatology ozone profiles are specified, and all aerosols are set to the pre-industrial levels. Land-sea distribution, land surface type, surface topography and ocean bathymetry are all maintained at their present-day conditions. Earth's orbital parameters are also fixed to the values appropriate for the present day (year 1990). These conditions have been fixed to be very similar to those employed in Voigt and Marotzke (2010) and Yang et al. (2012a,b), so as to enable detailed comparison of model sensitivities.

\section{Results}

We begin by comparing the results obtained using CCSM4 and CCSM3 for the purpose of the pre-industrial control experiments and in the $6 \%$ reduced solar radiation experiments; through these comparisons, we will establish the main differences between CCSM4 and CCSM3. We will next address the values for the hard Snowball Earth bifurcation points (above which runaway albedo feedback occurs) and the conditions for the existence of a soft Snowball Earth state in CCSM4.

Figure 1 shows the surface temperature $\left(T_{\mathrm{S}}\right)$, sea ice coverage, surface albedo, net cloud radiative forcing (CRF, shortwave plus longwave, at the top of the model) and poleward atmosphere and ocean energy transports under the pre-industrial forcings. The global mean $T_{\mathrm{S}}$ in CCSM4 is $285.6 \mathrm{~K}, 1.5 \mathrm{~K}$ lower than that in CCSM3, which is associated with low tropical and polar temperatures. In CCSM4, sea ice albedo and snow albedo are $0.61-0.65$ and $0.71-0.91$, respectively, both of which are greater than those in CCSM3, $0.43-0.50$ and 0.66-0.78 (Table 1). As shown in Figs. 1c and 2c, the combined sea ice/snow albedo in CCSM4 is about 00.2 greater than in CCSM3. Consequently, zonal mean $T_{\mathrm{S}}$ in CCSM4 in the north (south) polar region is about $8 \mathrm{~K}(5 \mathrm{~K})$ lower than in CCSM3. Over the Equator, $T_{\mathrm{S}}$ in CCSM4 is approximately $2 \mathrm{~K}$ lower than in CCSM3, which is mainly due to the stronger CRF in CCSM4 than in CCSM3, approximately -36 vs. $-22 \mathrm{~W} \mathrm{~m}^{-2}$ (Fig. 1d). Atmosphere energy transport at $40^{\circ} \mathrm{N}$ is $0-1.0 \mathrm{PW}\left(1 \mathrm{PW}=10^{15} \mathrm{~W}\right)$ larger in CCSM3 than in CCSM4. Poleward ocean energy transport is decreased by $\sim 0.5 \mathrm{PW}$ in the region poleward of $40^{\circ} \mathrm{S}$ in CCSM4.

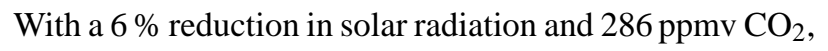
in CCSM4 the sea ice front extends to $40^{\circ} \mathrm{S} / \mathrm{N}$ and the global mean sea ice coverage reaches approximately $25 \%, 5 \%$ less than that in CCSM3 (Fig. 2), even though the sea ice/snow albedo in CCSM4 is greater than in CCSM3. The main reason for this is the stronger CRF in CCSM3; near the ice edge at $30^{\circ} \mathrm{S} / \mathrm{N}, \mathrm{CRF}$ (negative, cooling effect) in CCSM3 is $6-10 \mathrm{~W} \mathrm{~m}^{-2}$ stronger than in CCSM4 (Fig. 2d). There are no significant differences in atmospheric and oceanic energy transports except in the region poleward of $40^{\circ} \mathrm{S}$, where the southward ocean energy transport is about $0-0.6 \mathrm{PW}$ greater in CCSM3.

Figures 3 and 4 illustrate the integrated meridional overturning stream function for the Atlantic Ocean and for the global ocean, respectively. There are several readily apparent differences between CCSM4 and CCSM3: (1) The penetration depth of the North Atlantic Deep Water (NADW) is several hundred meters deeper in CCSM4 than in CCSM3, associated with the implementation of the new parameterization for density-driven overflows documented in Danabasoglu et al. (2010). (2) The Antarctic Bottom Water (AABW) transport in CCSM4 is much weaker than in CCSM3 (4 vs. $16 \mathrm{~Sv}$ ), mainly due to less brine rejection into the ocean in CCSM4 (Gent et al., 2011). On the other hand, the NADW transport is enhanced by about $2 \mathrm{~Sv}$ in CCSM4. (3) The mass stream function in the region of the Antarctic Circumpolar Current (ACC) is significantly reduced from 44 to $18 \mathrm{~Sv}$, partly due to the addition to the model of a parameterization for eddy-induced fluxes (Danabasoglu et al., 2012) and 

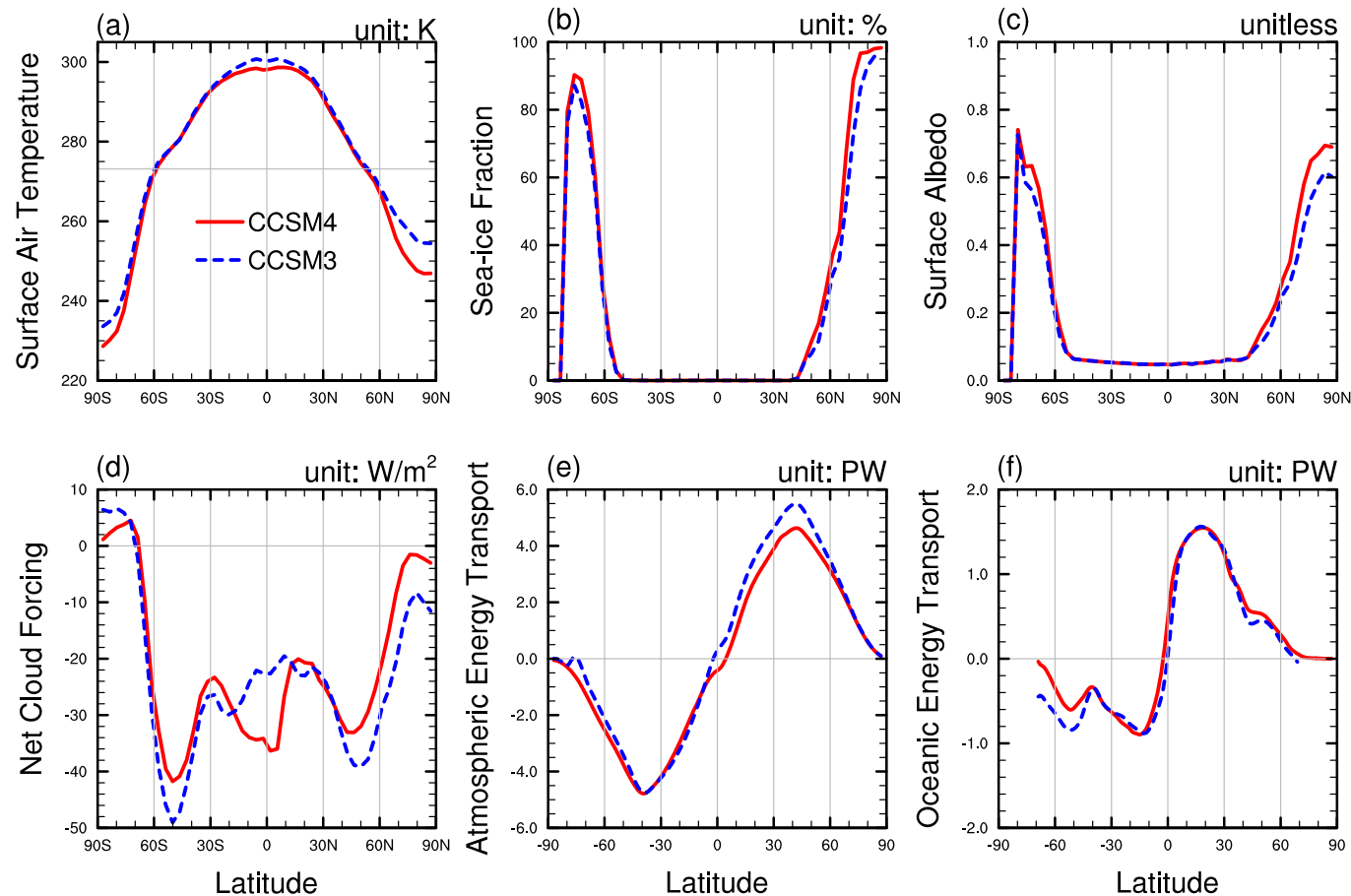

Fig. 1. CCSM4 (solid line) vs. CCSM3 (dashed line) for the pre-industrial control simulation. Annual and zonal mean surface air temperature (a), sea ice fraction (b), surface albedo (c), in this calculation, the land grid cells are excluded, net cloud radiative forcing at the top of the model ((d), longwave plus shortwave), northward atmosphere energy transport (e) and ocean energy transport (f). For ocean energy transport, in CCSM4 it includes the Eulerian mean and parameterized eddy, submesoscale and diffusive contributions, while the corresponding CCSM3 transport is for Eulerian mean component only.
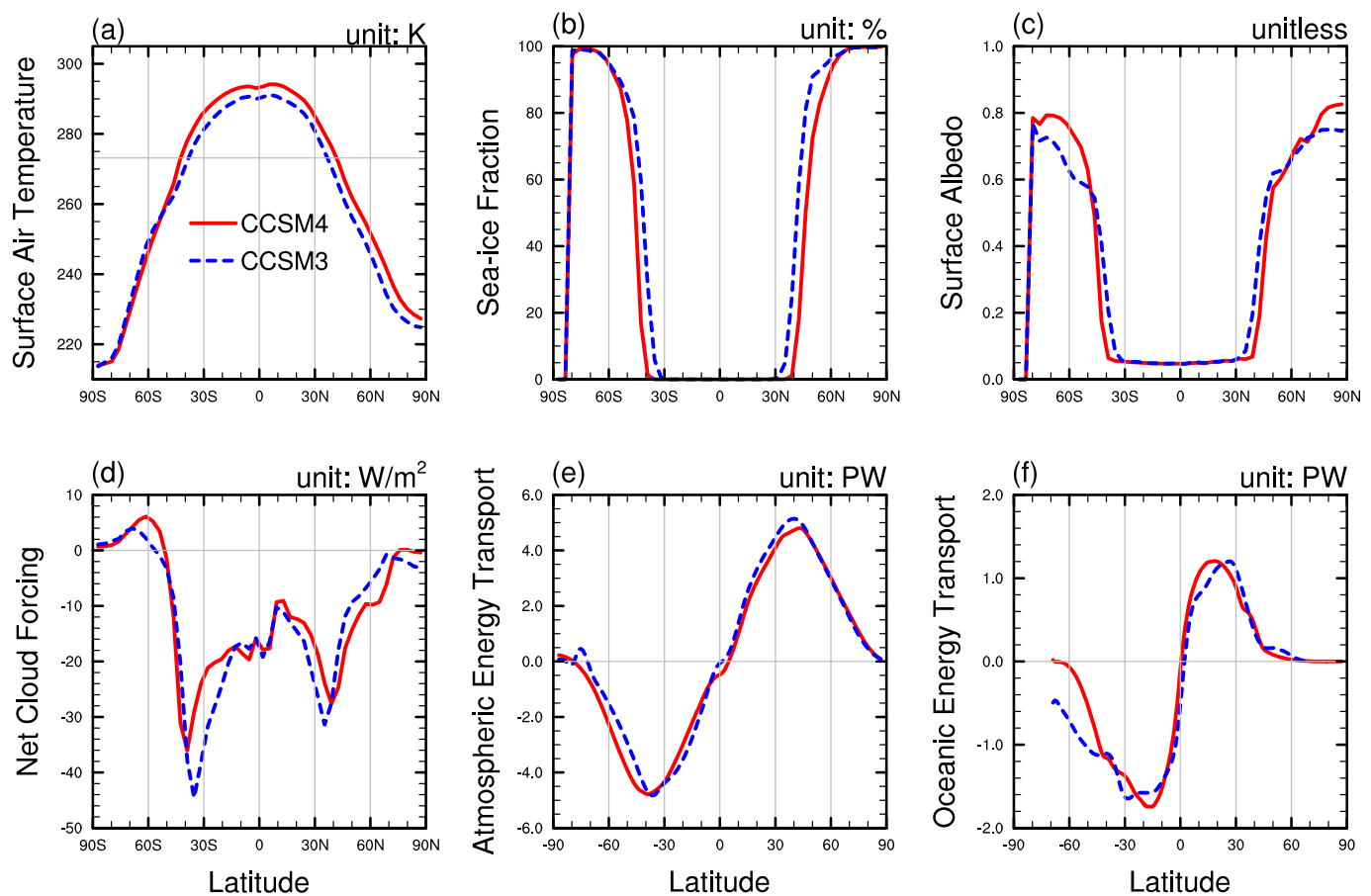

Fig. 2. Same as Fig. 1, but for the experiment with $94 \%$ solar radiation and $286 \mathrm{ppmv} \mathrm{CO}_{2}$. 
(a) CCSM4, PI

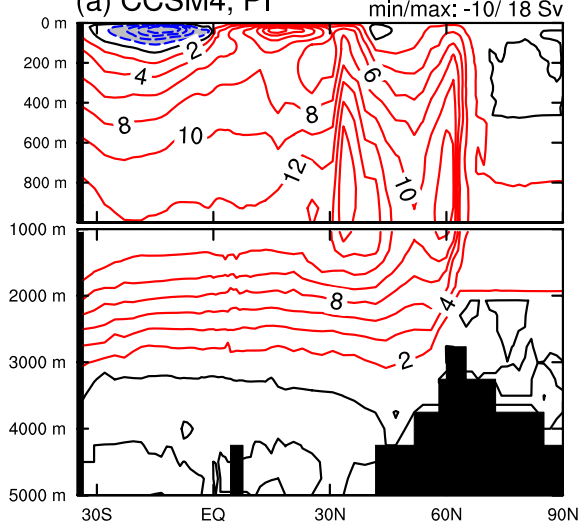

(c) $\operatorname{CCSM} 3, \mathrm{PI}$

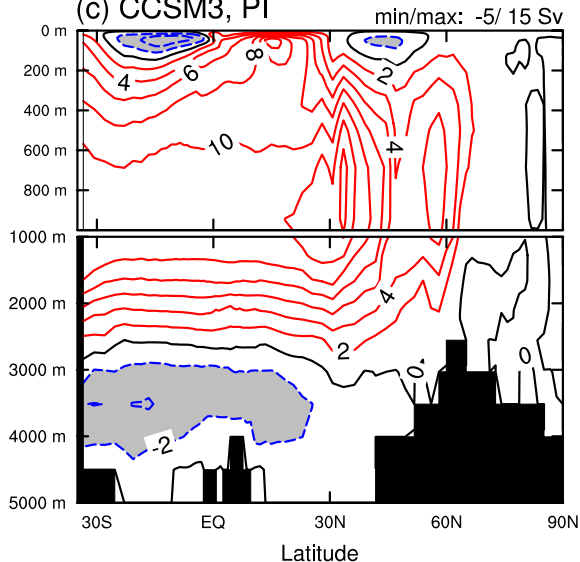

(b) CCSM4, 0.94TSI $\min / \max :-11 / 16 \mathrm{~Sv}$

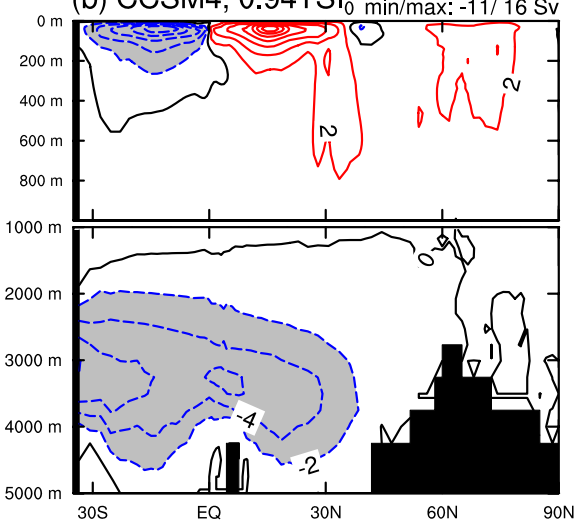

(d) $\mathrm{CCSM} 3,0.94 \mathrm{TSI} \mathrm{I}_{0} \mathrm{~min} / \mathrm{max}:-7 / 13 \mathrm{~Sv}$

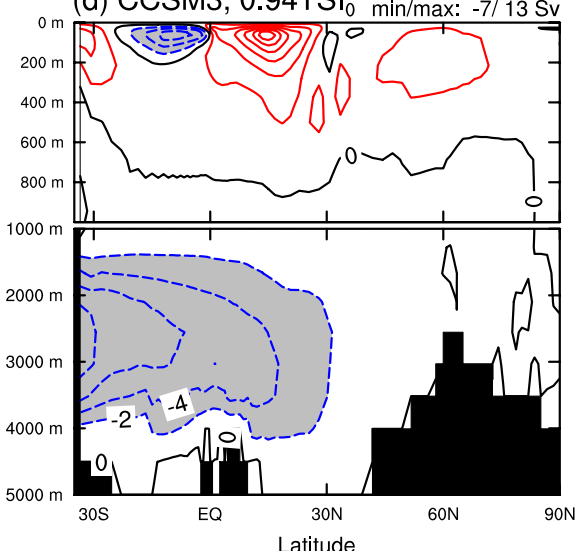

Fig. 3. Atlantic Ocean overturning circulation in CCSM4 (upper panel) and in CCSM3 (lower panel) for the pre-industrial case (PI) (a, c) and for the $94 \%$ total solar irradiance case $\left(0.94 \mathrm{TSI}_{0}\right.$, with $\left.286 \mathrm{ppmv} \mathrm{CO}_{2}\right)(\mathbf{b}, \mathbf{d})$. CCSM4 transports include the Eulerian mean and parameterized eddy and submesoscale contributions, whereas CCSM3 transports are for the Eulerian mean component only. The contour interval is $2 \mathrm{~Sv}$.

partly due to relatively weak zonal wind stress driving the ocean in CCSM4 (Gent et al., 2011). This aspect of the Southern Ocean circulation is in much closer accord with the observations of Orsi et al. (2002). (4) In CCSM4 the subtropical-tropical cells (STCs, wind-driven circulations) are several sverdrups greater than in CCSM3. All of these results are qualitatively consistent with those in high-resolution versions of CCSM4 and CCSM3 described by Danabasoglu et al. (2012).

In response to a reduction of the solar constant, the trends of the circulation pattern are similar between CCSM4 and CCSM3: NADW formation becomes weaker, AABW formation and STC circulations become stronger (for further details, please see Yang et al., 2012b). However, in CCSM4, the clockwise circulation in the latitudes of ACC is transformed to a robust counter-clockwise circulation, likely arising from the added parameterization of oceanic near-surface eddies (Danabasoglu et al., 2008). For the atmospheric mass stream function, the strength and extent of the Hadley cells are very similar between CCSM3 and CCSM4 (not shown).

The analyses above demonstrate that between CCSM4 and CCSM3 the main differences are in sea ice/snow albedo and cloud radiative forcings. In CCSM3, the low sea ice/snow albedo is used to compensate the overly small downward solar radiation at the surface caused by a bias due to too much low cloud in the polar regions (Collins et al., 2006a; Vavrus and Waliser, 2008). In CCSM4, this bias has been alleviated (Vavrus and Waliser, 2008) and the sea ice/snow albedo now is in good agreement with observations. Notably, there are significant differences in cloud radiative forcings between CCSM3 and CCSM4, which exerts important influences on the surface temperature and on the sea ice advance. From CCSM3 to CCSM4, the strength and extent of the ocean overturning circulations have also been modified significantly, but the integrated ocean energy transport shows slight changes (except in the region of the ACC), which should be expected from the compensations among different 
(a) CCSM4, PI

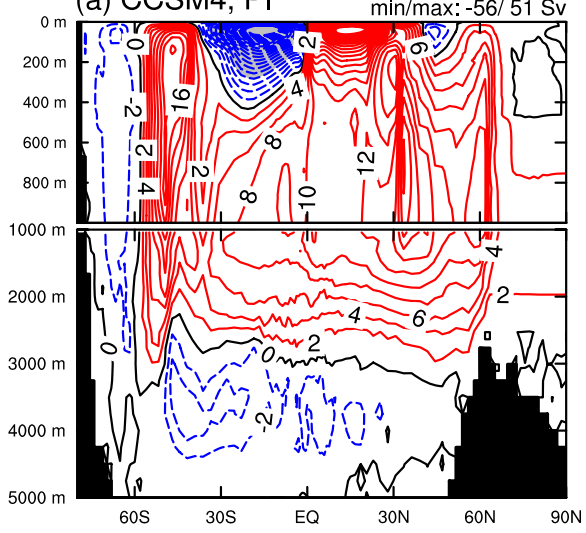

(c) CCSM3, P

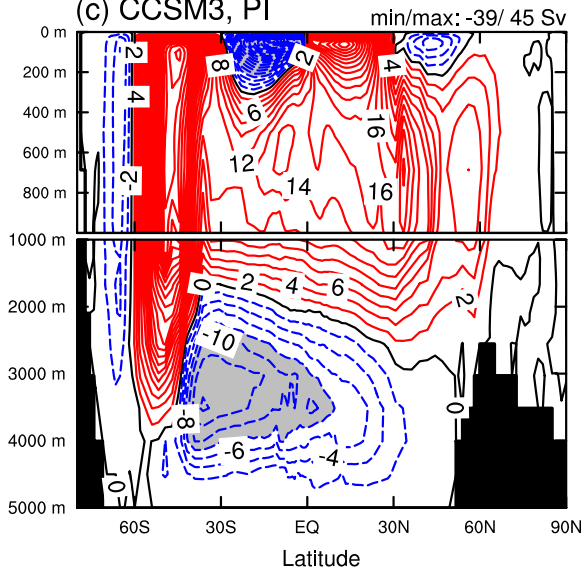

(b) CCSM4, 0.94TSI $\min / \max :-58 / 52 \mathrm{~Sv}$

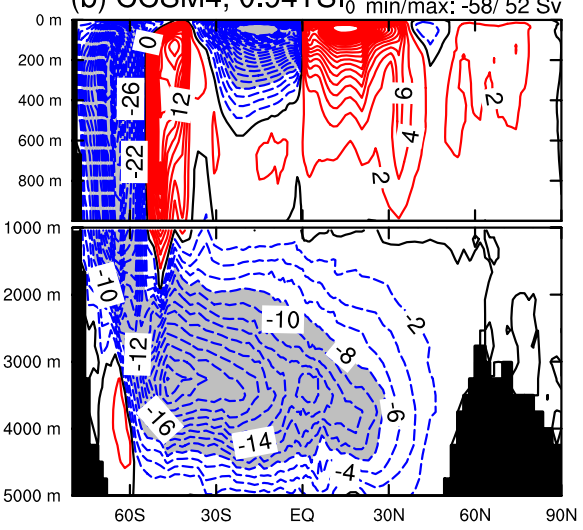

(d) CCSM3, 0.94TSI $\min / \max :-47 / 47 \mathrm{~Sv}$

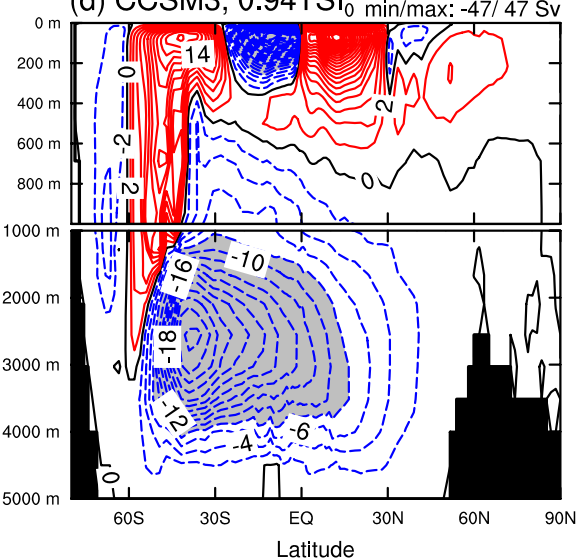

Fig. 4. Same as Fig. 3, but for the global ocean.

regions. However, as the sea ice approaches the tropics, the differences in atmosphere and ocean heat transports between CCSM4 and CCSM3 are amplified, as we will demonstrate in what follows.

In the next step in this series of analyses, we investigate the initiation processes of a modern Snowball Earth in CCSM4. Sea ice evolution is investigated in a first set of experiments with differing solar constants but fixed $\mathrm{CO}_{2}$ concentration and in a second group of experiments with different $\mathrm{CO}_{2}$ concentrations but fixed solar constant. The results for these two sets of experiments are shown in Fig. 5a and b, respectively. Figure 6 shows the sea ice evolution with different initial conditions under the same forcing of $94 \%$ solar radiation and 100 or $120 \mathrm{ppmv}^{\mathrm{CO}} \mathrm{CO}_{2}$. In our pervious study with CCSM3 (Yang et al., 2012a,b), it was found that runaway glaciation occurs for a $10-10.5 \%$ reduction in solar radiation with $286 \mathrm{ppmv} \mathrm{CO}_{2}$ or a $6 \%$ reduction in solar radiation with $17.5-20$ ppmv $\mathrm{CO}_{2}$. In CCSM4, the current analyses show that the threshold is an $8-9 \%$ reduction in solar radiation with $286 \mathrm{ppmv} \mathrm{CO}_{2}$ or a $6 \%$ reduction in solar radiation with 70-100 ppmv $\mathrm{CO}_{2}$ (Fig. 5). The main reason for the difference in the bifurcation points for the two models is connected with the higher sea ice/snow albedo in CCSM4. Differences in cloud radiative forcings and poleward atmosphere and ocean energy transports also affect the forcings required to trigger a hard Snowball Earth.

Notably, when the sea ice fraction reaches $\sim 45 \%$, it jumps abruptly to $\sim 60 \%$ in approximately 20 model years, which is due to the positive feedback associated with the Hadley cells. As the sea ice fronts enter the tropics, the near-surface branch of the Hadley cells (trade winds) transports relatively cold air to the sea ice fronts (Bendtsen, 2002) and meanwhile the strong stresses associated with the trade winds enhance the sea ice flow velocity (Yang et al., 2012a,b), both of which amplify the equatorward expansion of the sea ice. In other words, there exist no stable states between 45-60\% sea ice coverage, consistent with the results in CCSM3 (see Fig. 3 of Yang et al., 2012a). Furthermore, in all of the experiments shown in Figs. 5 and 6, as sea ice coverage reaches approximately $60-65 \%$ and the corresponding sea ice edge approaches $\sim 10^{\circ} \mathrm{S}$ and $30^{\circ} \mathrm{N}$ latitudes (Fig. $7 \mathrm{a}$ and b), the growth rate of the sea ice significantly decreases, and in some cases the sea ice margin remains stable near these latitudes without entering a hard Snowball Earth state. From Fig. 5, it 

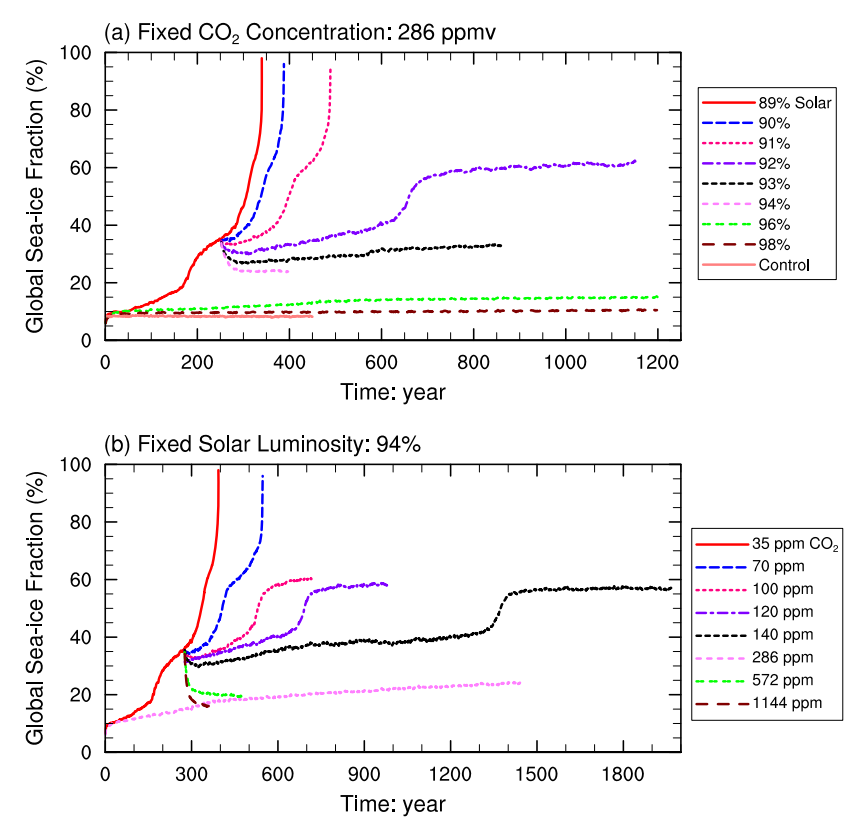

Fig. 5. Sea ice evolution in two groups: fixed $\mathrm{CO}_{2}$ concentration (286 ppmv) but with different solar constants (a), and fixed the solar constant ( $94 \%$ of the present-day level) but with different $\mathrm{CO}_{2}$ levels (b). In (a), the experiments with 90-94\% solar radiation are initiated from the 251th year of the case with $89 \%$ solar radiation; in (b), the experiments with 70-120 and 572-1144 ppmv $\mathrm{CO}_{2}$ are initiated from the 276th year of the case with $35 \mathrm{ppmv} \mathrm{CO}_{2}$; other experiments are initiated from the present-day climate.

is clear that this feature does not depend on the strength of the solar radiation or $\mathrm{CO}_{2}$ forcing, and in Fig. 6, it is found that it is also independent of the initial conditions. These results imply that there are internal processes that act to effectively prevent the runaway albedo feedback from occurring. In CCSM3, there is no indication of this phenomenon (Yang et al., 2012a,b), nor does it appear to exist in other models, such as the Fast Ocean Atmosphere Model (Poulsen and Jacob, 2004) or the fully coupled atmosphere-ocean model ECHAM5/MPI-OM (Voigt and Marotzke, 2010; Voigt et al., 2011). It is clearly important to know the cause of this distinguishing feature in CCSM4. By investigation of the differences between CCSM4 and CCSM3, we will be able to provide an answer to this important question and thereby establish one of the original results of this new series of analyses.

To this end, we have analysed the results from the case of $94 \%$ insolation and 100 ppmv $\mathrm{CO}_{2}$ in CCSM4 and from the case of $94 \%$ insolation and 50 ppmv $\mathrm{CO}_{2}$ in CCSM3. We choose these two experiments as a basis for comparison, because both enter a near-Snowball state (Fig. 7) and the final equilibrium sea ice coverages are similar. Although in this comparison the $\mathrm{CO}_{2}$ forcing in CCSM4 is $\sim 2.66 \mathrm{~W} \mathrm{~m}^{-2}$ stronger (Collins et al., 2006b) than that in CCSM3, its influence over the sea ice/snow would be compensated by the relatively high sea ice/snow albedo in CCSM4. The sea ice

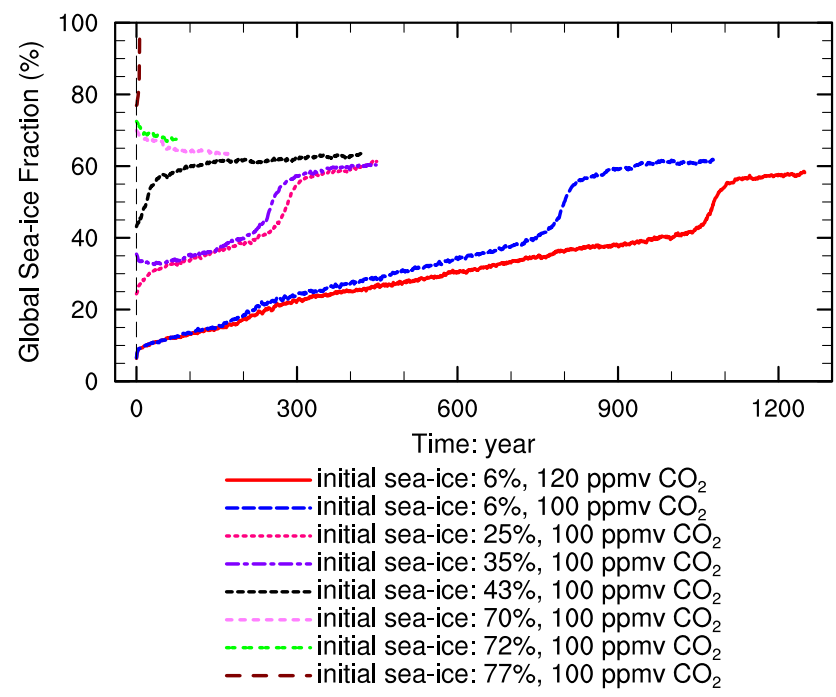

Fig. 6. Sea ice evolution in the cases with $94 \%$ solar radiation and 120 or 100 ppmv $\mathrm{CO}_{2}$ under different initial conditions. The eight experiments start from the present-day climate ( $\sim 6 \%$ sea ice), the 1401 th year of the case with $94 \%$ solar radiation and $286 \mathrm{ppmv}$ $\mathrm{CO}_{2}$ ( $\sim 25 \%$ sea ice, a quasi-equilibrium state), the 276th year of the case with $94 \%$ solar radiation and $35 \mathrm{ppmv} \mathrm{CO}_{2}(\sim 35 \%$ sea ice, a transient state, same as that in Fig. 5b), the 1326th year of the case with $94 \%$ solar radiation and 140 ppmv $\mathrm{CO}_{2}(\sim 43 \%$ sea ice, a quasi-equilibrium state), the 526th year ( $\sim 70 \%$ sea ice, a transient state), the 531th year ( $\sim 2 \%$ sea ice, a transient state) and the 536th year ( $\sim 77 \%$ sea ice, a transient state) of the case with $94 \%$ solar radiation and $70 \mathrm{ppmv} \mathrm{CO}_{2}$, respectively.

evolution during the integration period and the final equilibrium states are shown in Figs. 8 and 9, respectively. In these two cases, global mean sea ice coverage and $T_{\mathrm{S}}$ are very similar, approximately $60 \%$ and $254 \mathrm{~K}$, respectively, but the meridional distributions are quite different. In CCSM3 the sea ice distribution is more symmetrical about the Equator; in CCSM4, the sea ice is closer to the Equator in the SH and further from the Equator in the NH. Moreover, in CCSM4 surface air temperature is higher in the $\mathrm{NH}$ and lower in the SH than in CCSM3.

From Fig. 8, it is found that the sea ice growth rate in the $\mathrm{SH}$ is much greater than in the $\mathrm{NH}$ in both CCSM3 and CCSM4, consistent with the results in ECHAM5/MPIOM (Voigt and Marotzke, 2010). This is due to two factors: (1) the surface albedo over snow/ice-covered regions of the SH is greater than that over snow-free land areas of the $\mathrm{NH}$ and (2) the cloud radiative forcing in the $\mathrm{SH}$ is about $10 \mathrm{~W} \mathrm{~m}^{-2}$ stronger (negative, cooling effect) than in that of the NH (Figs. 1d, 2d, and 9d), both of which enhance the surface cooling (Figs. 1a, 2a and 9a) and thereby support the sea ice growth and expansion in the SH. Furthermore, in the early stage of evolution, the sea ice growth in CCSM4 is much slower than in CCSM3, likely arising from the relatively weak cloud radiative forcing and the stronger $\mathrm{CO}_{2}$ 


\section{SOFT SNOWBALL SOLUTIONS}
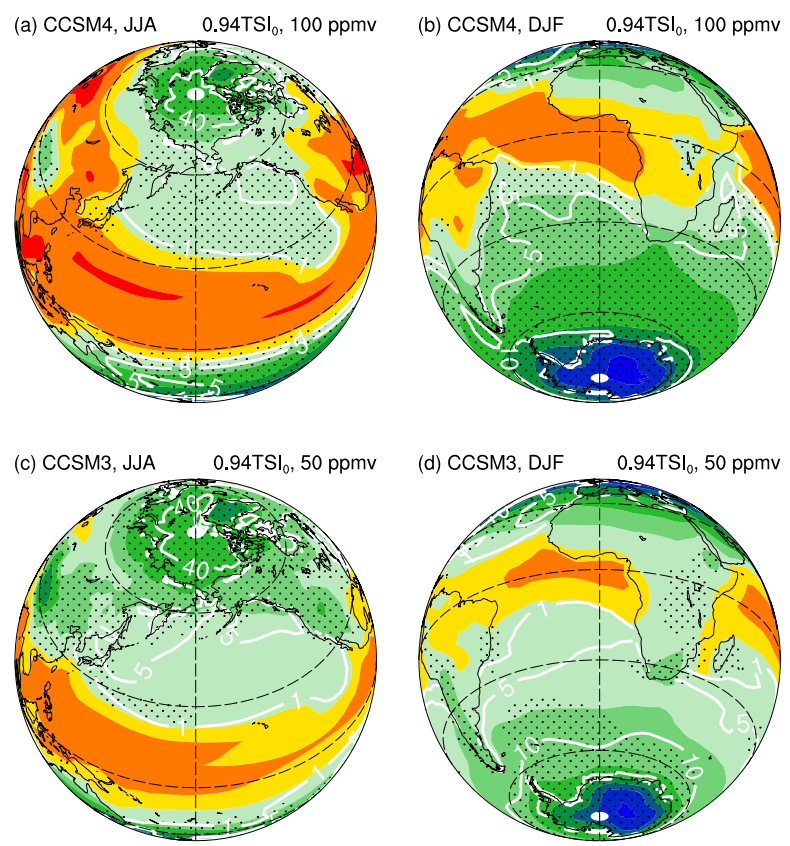

(d) CCSM3, DJF $\quad 0.94 \mathrm{TSI}_{0}, 50 \mathrm{ppmv}$

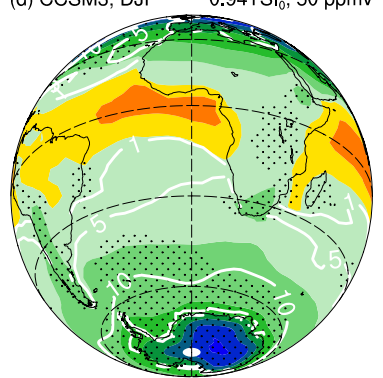

$\mathrm{T}_{\mathrm{S}}\left({ }^{\circ} \mathrm{C}\right)$

Fig. 7. Modern soft Snowball Earth solutions in CCSM4 (upper panel, $94 \%$ solar radiation and $100 \mathrm{ppmv} \mathrm{CO}_{2}$ ) and in CCSM3 (lower panel, $94 \%$ solar radiation and 50 ppmv $\mathrm{CO}_{2}$ ). Surface air temperature $\left({ }^{\circ} \mathrm{C}\right.$, color shaded), sea ice thickness ( $\mathrm{m}$, white lines) and snow-covered regions ( $>0.04 \mathrm{~m}$, stippled) in June-July-August $(\mathrm{JJA}, \mathbf{a}, \mathbf{c})$ and in December-January-February (DJF, b, d).

radiative forcing over the oceans in CCSM4, as mentioned earlier. However, in the $\mathrm{SH}$, as the sea ice moves closer to the tropics, the high sea ice/snow albedo in CCSM4 greatly enhances the albedo feedback, so that the sea ice extent abruptly increases from approximately 110 to $160 \times 10^{6} \mathrm{~km}^{2}$ (Fig. 8a). Interestingly and importantly, as the sea ice approaches the Equator in the $\mathrm{SH}$, it does not across the Equator owning to the increased cross-equatorial heat transport. There is a 4.2 PW transport of energy across the Equator from the $\mathrm{NH}$ to the SH by atmospheric and oceanic processes (Fig. 9e and f); this transport averages to a net cooling of $16.8 \mathrm{~W} \mathrm{~m}^{-2}$ in the $\mathrm{NH}$ and a compensating warming of $16.8 \mathrm{~W} \mathrm{~m}^{-2}$ in the $\mathrm{SH}$, which effectively prohibits the cross-equatorial expansion of the sea ice. We expect the asymmetry in sea ice advance associated with the differences in hemispheric continentality to play an important role in determining the bifurcation points for Snowball transition due to the introduction of realistic land-sea distributions in our next phase of Neoproterozoic climate simulation.

In the $\mathrm{NH}$, the expansion of the sea ice in CCSM4 is much slower than in CCSM3 and the sea ice fronts in CCSM4 are out of the domain of the Hadley cells during the entire integration. This is due primarily to the fact that in CCSM4 a

greater fraction of land is snow-free in boreal summer and the surface is warm $\left(0-15^{\circ} \mathrm{C}\right.$, Fig. 7a), which would support heat transports to the downstream oceans and inhibit the growth of sea ice in these regions. Moreover, over the open water, in CCSM4 the cloud radiative forcing is about $6-10 \mathrm{~W} \mathrm{~m}^{-2}$ weaker than in CCSM3, and the surface air temperatures over the open oceans are $\sim 4 \mathrm{~K}$ higher than in CCSM3, which act to prevent the equatorward advance of the sea ice.

Therefore, it is the combination of atmosphere and ocean dynamics, cloud radiative forcing and less snow over land that suppresses the spread of the sea ice and promotes the existence of open-water equatorial oceans in CCSM4. Following the definition of a "soft Snowball" Earth in Yang et al. (2012a), i.e., sea ice margins enter the tropics, sea ice coverage is higher than $50 \%$ and less than $100 \%$, and a significant area of the tropical continents is covered by perennial snow, CCSM4 solutions with 60-65\% sea ice coverage under 100140 ppmv $\mathrm{CO}_{2}$, and $94 \%$ solar radiation should be viewed as "soft Snowball" Earth states (Figs. 5-7). Although the snowcovered land regions are quite limited in CCSM4 (Fig. 7a and b), it should be kept in mind that these regions would become covered by thick continental ice sheets on the long timescale of million years and these ice sheets would "flow" into the remaining tropical continents, as discussed in Hyde et al. (2000), Pollard and Kasting (2004), Peltier et al. (2004, 2007), and Liu and Peltier (2010, 2011).

\section{Discussion and conclusions}

In comparison with CCSM3, we find that CCSM4 is able to enter a globally ice-covered state somewhat more easily. However, the requirements in CCSM4 for an 8-9\% reduced solar luminosity and $286 \mathrm{ppmv} \mathrm{CO}_{2}$ or a $6 \%$ reduced solar luminosity with $70-100 \mathrm{ppmv} \mathrm{CO}_{2}$, may still not be met by the expected conditions of the Neoproterozoic. For the solar luminosity, compared with the present-day level, the Neoproterozoic sun was only about $5.0-6.7 \%$ fainter at 635 million years ago (the time of the onset of the Marinoan glaciation) and about $5.3-7.4 \%$ fainter at 715 million years ago (the time of the onset of the Sturtian glaciation) (Gough, 1981; Crowley and Baum, 1993).

In so far as the concentration of carbon dioxide is concerned, it is poorly known. For the Neoproterozoic ice ages, several models have been employed to examine the $\mathrm{CO}_{2}$ level. Donnadieu et al. (2004) reported, based on results of a coupled climate-geochemical model, that the atmospheric $\mathrm{CO}_{2}$ amount would decrease from an initial level of $1830 \mathrm{ppmv}$ (assumed) to a low level of $250 \mathrm{ppmv}$ by enhanced continental weathering associated with changes in run-off and eruptions of fresh basaltic provinces as a result of the break-up of the supercontinent of Rodinia. However, Peltier et al. (2007) and Liu and Peltier (2011) have argued, based on the results of a carbon cycle coupled climate model, that oceanic dissolved organic carbon would 

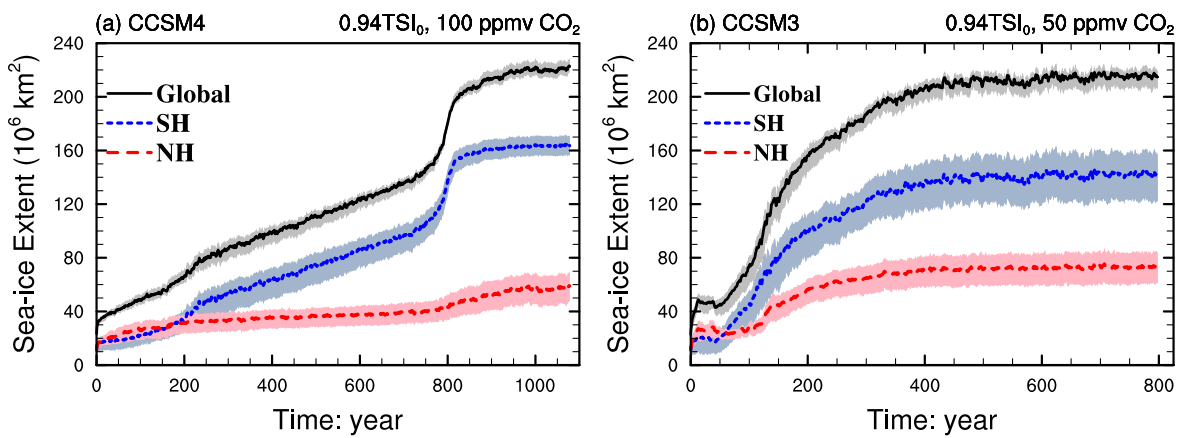

Fig. 8. CCSM4 (a) vs. CCSM3 (b): sea ice evolution in the Northern Hemisphere (NH, red line), in the Southern Hemisphere (SH, blue line) and for total (Global, black line). Shaded area shows the range of the seasonal cycle. Note: the ocean area is $205 \times 10^{6} \mathrm{~km}^{2}$ in the $\mathrm{SH}$ and $154 \times 10^{6} \mathrm{~km}^{2}$ in the $\mathrm{NH}$, and the entire Earth's surface area is $510 \times 10^{6} \mathrm{~km}^{2}$.
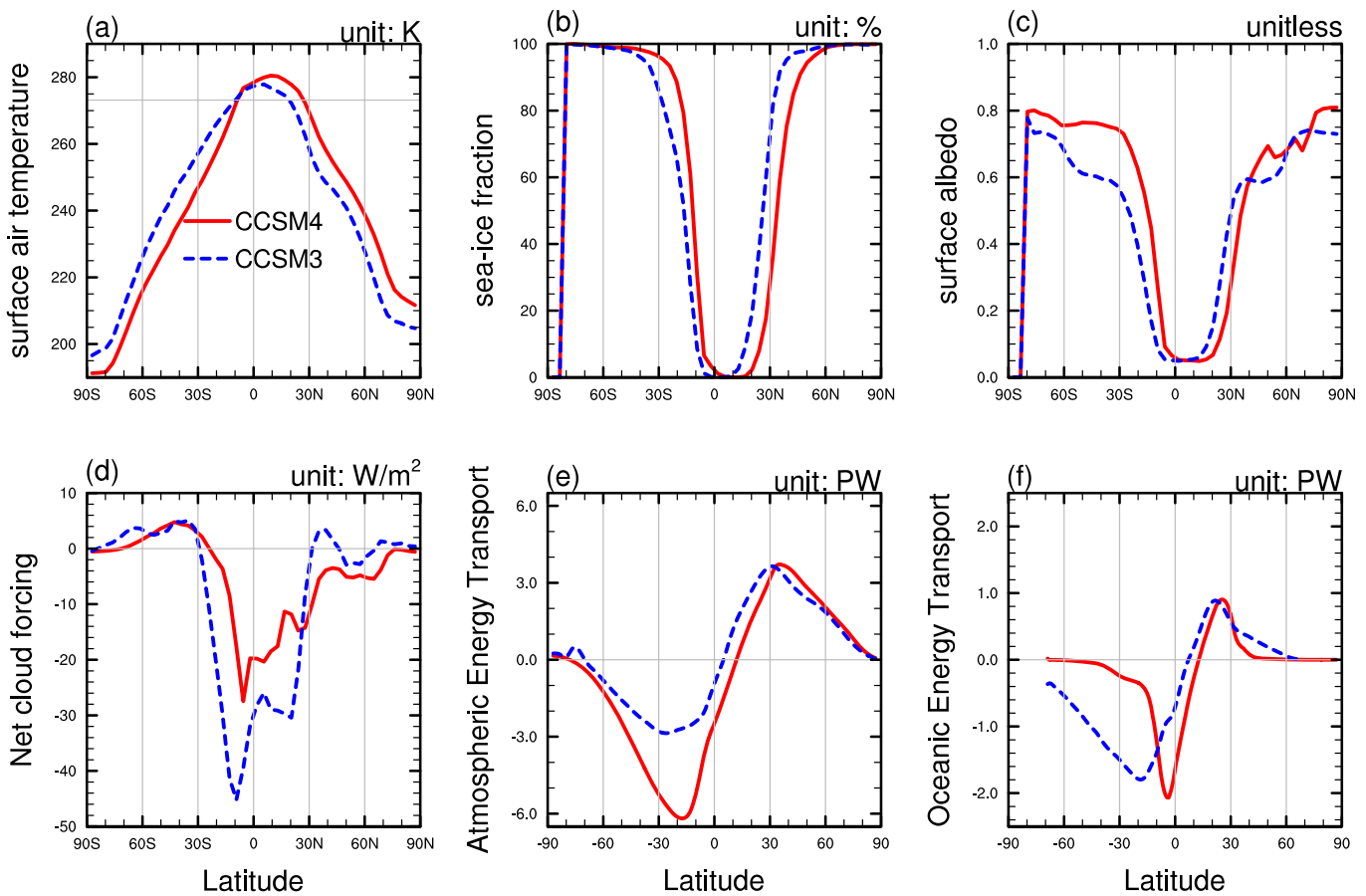

Fig. 9. CCSM4 (solid line) vs. CCSM3 (dashed line). Same as Fig. 1, but for the case of $94 \%$ solar radiation with $100 \mathrm{ppmv}^{\mathrm{CO}} 2$ in $\mathrm{CCSM}_{4}$ and for the case of $94 \%$ solar radiation with $50 \mathrm{ppmv} \mathrm{CO}_{2}$ in CCSM3.

be converted into inorganic carbon as the system cooled and oxygen was drawn down into the Neoproterozoic ocean, and the inorganic carbon thereafter released into atmosphere (see also Rothman et al., 2003). The remineralization of organic carbon might well prohibit the atmospheric $\mathrm{CO}_{2}$ concentration from dropping to the very low level required for global glaciation to occur. Because these two models are highly parameterized, however, there exists uncertainty in the results. More comprehensive models employing these physical processes need to be developed.

In CCSM4, it is found that the maximum sea ice cover that is stable is approximately $65 \%$ (Fig. 6) smaller than that in CCSM3 (76\%, Yang et al., 2012a) but larger than in the
ECHAM5/MPI-OM (55\%, Voigt and Marotzke, 2010; Voigt et al., 2011). The main reason for this divergence is the different sea ice/snow albedos employed in these different models. The sea ice albedo is $0.43-0.50$ in CCSM3, $0.61-0.65$ in CCSM4, and 0.55-0.75 in ECHAM5/MPI-OM. Increasing the sea ice/snow albedo will lead to a smaller value for the maximum sea ice cover (Yang et al., 2012a).

In Pierrehumbert et al. (2011) and Abbot et al. (2011), it was argued that low sea ice/snow albedo is a necessary condition for the existence of a near-Snowball Earth state, which is in significant degree in contrast to the results obtained using CCSM3 or CCSM4. It is found in fact that, after including an active ocean, a near-Snowball Earth state 
exists in circumstances in which the sea ice albedo may be as high as 0.60 in CCSM3 (Yang et al., 2012a) or 0.61-0.65 in CCSM4, and the snow albedo may be as high as 0.71-0.91 in CCSM4. The ocean dynamics aid and abet the persistence of open-water oceans at low latitudes even under extremely cold global conditions.

In the previous analyses presented in Yang et al. (2012a), it was proposed that as sea ice moves to low latitudes, the area coverage of melt ponds over the sea ice would increase due to the fact of that solar insolation at low latitudes is much greater than at high latitudes. In CCSM4 for the purpose of both reproducing the preindustrial climate and simulating the Snowball Earth climates, it is found that the melt pond fraction in the summer is less than $10 \%$, much less than observations (as high as $40 \%$ in the Arctic, Perovich et al., 2002), and its trend is unclear (not shown). In CCSM4, the influence of the melt ponds remains highly parameterized (Holland et al., 2012); a more complete and realistic representation of melt pond processes should be incorporated into the model.

As a summary, the issues of the radiative forcings required to trigger a modern "hard Snowball" and a modern "soft Snowball" Earth have been investigated using the coupled atmosphere-ocean model CCSM4. Owing to the uncertainties in model parameterizations, the absence of land ice sheets and the modern geography used in the simulations, we cannot exclude the possibility of a "hard Snowball" Earth. More importantly, however, our results confirm that a "soft Snowball" Earth solution is an equally tenable solution to the Neoproterozoic climate puzzle.

Acknowledgements. We thank G. Vettoretti for providing the data for CCSM3 and CCSM4 preindustrial runs. Y. Hu and J. Yang are supported by the National Basic Research Program of China (973 Program, 2010CB428606) and the National Natural Science Foundation of China under grant 41025018. J. Yang is partially supported by the Over-sea Study Program for Graduate Students of the China Scholarship Council. W. R. Peltier is supported by the Canadian Foundation for Climate and Atmospheric Science and a consortium of Canadian universities and by NSERC Discovery Grant A9627. The required computations were performed on the SciNet facility at the University of Toronto, which is a component of the Compute Canada HPC platform.

Edited by: A. Haywood

\section{References}

Abbot, D. S., Voigt, A., and Koll, D.: The Jormungand global climate state and implications for the Neoproterozoic snowball paradox, J. Geophys. Res., 116, D18103, doi:10.1029/2011JD015927, 2011.

Allen, P. A. and Etienne, J. L.: Sedimentary challenge to Snowball Earth, Nat. Geosci., 1, 817-825, 2008.
Baum, S. K. and Crowley, T. J.: GCM response to Late Precambrian ( $\sim 590 \mathrm{Ma})$ ice-covered continents, Geophys. Res. Lett., 28, 583 586, 2001.

Bendtsen, J.: Climate sensitivity to changes in solar insolation in a simple coupled climate model, Clim. Dynam., 18, 595-609, 2002.

Briegleb, B. P. and Light, B.: A Delta-Eddington multiple scattering parameterization for solar radiation in the sea ice component of the Community Climate System Model, NCAR Tech. Note 472+STR, 100 pp., 2007.

Budyko, M. I.: Effect of solar radiation variations on climate of Earth, Tellus, 21, 611-619, 1969.

Chandler, M. A. and Sohl, L. E.: Climate forcings and the initiation of low-latitude ice sheets during the Neoproterozoic Varanger glacial interval, J. Geophys. Res., 105, 20737-20756, 2000.

Collins, W. D., Bitz, C. M., Blackmon, M. L., Bonan, G. B., Bretherton, C. S., Carton, J. A., Chang, P., Doney, S. C., Hack, J. J., Henderson, T. B., Kiehl, J. T., Large, W. G., Mckenna, D. S., Santer, B. D., and Smith, R. D.: The Community Climate System Model version 3 (CCSM3), J. Climate, 19, 2122-2143, 2006a.

Collins, W. D., Ramaswamy, V., Schwarzkopf, M. D., Sun, Y., Portmann, R. W., Fu, Q., Casanova, S. E. B., Dufresne, J.-L., Fillmore, D. W., Forster, P. M. D., Galin, V. Y., and Gohar, L. K.: Radiative forcing by well-mixed greenhouse gases: Estimates from climate models in the Intergovernmental Panel on Climate Change (IPCC) Fourth Assessment Report (AR4), J. Geophys. Res., 111, D14317, doi:10.1029/2005JD006713, 2006b.

Crowley, T. J. and Baum, S. K.: Effect of decreased solar luminosity on Late Precambrian ice extent, J. Geophys. Res., 98, 16723$16732,1993$.

Danabasoglu, G., Ferrari, R., and McWilliams, J. C.: Sensitivity of an ocean general circulation model to a parameterization of nearsurface eddy fluxes, J. Climate, 21, 1192-1208, 2008.

Danabasoglu, G., Large, W. G., and Briegleb, B. P.: Climate impacts of parameterized Nordic Sea overflows, J. Geophys. Res., 115, C11005, doi:10.1029/2010JC006243, 2010.

Danabasoglu, G., Bates, S., Briegleb, B. P., Jayne, S. R., Jochum, M., Large, W. G., Peacock, S., and Yeager, S. G.: CCSM4 Ocean Component, J. Climate, 25, 1361-1389, 2012.

Donnadieu, Y., Godderis, Y., Ramstein, G., Nedelec, A., and Meert, J. G.: A "snowball Earth" climate triggered by continental break-up through changes in runoff, Nature, 418, 303-306, 2004.

Flocco, D., Feltham, D. L., and Turner, A. K.: Incorporation of a physically based melt pond scheme into the sea ice component of a climate model, J. Geophys. Res., 115, C08012, doi:10.1029/2009JC005568, 2010.

Gent, P. R., Danabasoglu, G., Donner, L. J., Holland, M. M., Hunke, E. C., Jayne, S. R., Lawrence, D. M., Neale, R. B., Rasch, P. J., Vertenstein, M., Worley, P. H., Yang, Z.-L., and Zhang, M.: The community climate system model version 4, J. Climate, 24, 4973-4991, 2011.

Gough, D. O.: Solar interior structure and luminosity variations, Solar Phys., 74, 21-34, 1981.

Hoffman, P. F. and Schrag, D. P.: The Snowball Earth hypothesis: testing the limits of global change, Terra Nova, 14, 129-155, 2002. 
Hoffman, P. F., Kaufman, A. J., Halverson, G. P., and Schrag, D. P.: A Neoproterozoic Snowball Earth, Science, 281, 1342-1346, 1998.

Holland, M. M., Bailey, D. A., Briegleb, B. P., Light, B., and Hunke, E.: Improved sea ice shortwave radiation physics in CCSM4: the impact of melt ponds and aerosols on Arctic sea ice, J. Climate, 25, 1413-1430, 2012.

Hunke, E. C. and Lipscomb, W. H.: CICE: the Los Alamos sea ice model users manual, version 4, Los Alamos National Laboratory Tech. Report, LA-CC-06-012, 76 pp., 2008.

Hyde, W. T., Crowley, T. J., Baum, S. K., and Peltier, W. R.: Neoproterozoic Snowball Earth simulations with a coupled climate/icesheet model, Nature, 405, 425-429, 2000.

Kirschvink, J. L.: Late Proterozoic Low-Latitude Global Glaciation: The Snowball Earth, The Proterozoic Biosphere, edited by: Schopf, J. W. and Klein, C., Cambridge University Press, Cambridge, 51-52, 1992.

Lawrence, D. M., Oleson, K. W., Flanner, M. G., Thornton, P. E., Swenson, S. C., Lawrence, P. J., Zeng, Z., Yang, Z.-L., Levis, S., Sakaguchi, K., Bonan, G. B., and Slater, A. G.: Parameterization improvements and functional and structural advances in version 4 of the Community Land Model, J. Adv. Model. Earth Syst., 3, M03001, doi:10.1029/2011MS000045, 2011.

Lewis, J. P., Weaver, A. J., Johnston, S. T., and Eby, M.: Neoproterozoic "snowball Earth": dynamic sea ice over a quiescent ocean, Paleoceanography, 18, 1092, doi:10.1029/2003PA000926, 2003.

Lewis, J. P., Weaver, A. J., and Eby, M.: Snowball versus Slushball Earth: dynamic versus nondynamic sea ice?, J. Geophys. Res., 112, C11014, doi:10.1029/2006JC004037, 2007.

Liu, Y. and Peltier, W. R.: A carbon cycle coupled climate model of Neoproterozoic glaciation: Influence of continental configuration on the formation of a "soft Snowball", J. Geophys. Res., 115, D17111, doi:10.1029/2009JD013082, 2010.

Liu, Y. and Peltier, W. R.: A carbon cycle coupled climate model of Neoproterozoic glaciation: Explicit carbon cycle with stochastic perturbations, J. Geophys. Res., 116, D02125, doi:10.1029/2010JD015128, 2011.

Neale, R. B., Richter, J. H., and Jochum, M.: The impact of convection on ENSO: From a delayed oscillator to a series of events, J. Climate, 21, 5904-5924, 2008.

Neale, R. B., Richter, J., Park, S., Lauritzen, P. H., Vavrus, S. J., Rasch, P. J., and Zhang, M.: The mean climate of the Community Atmosphere Model (CAM4) in forced SST and fully coupled experiments, J. Climate, submitted, 2011.

Orsi, A. H., Smethie, W. M., and Bullister, J. L.: On the total input of Antarctic waters to the deep ocean: A preliminary estimate from chlorofluorocarbon measurements, J. Geophys. Res., 107, 3122, doi:10.1029/2001JC000976, 2002.

Peltier, W. R. and Solheim, L.: The climate of the Earth at Last Glacial Maximum: statistical equilibrium state and a model of clmate variability, Quaternary Sci. Rev., 23, 335-357, 2004.

Peltier, W. R., Tarasov, L., Vettoretti, G., and Solheim, L. P.: Climate dynamics in deep time: modeling the "Snowball bifurcation" and assessing the plausibility of its occurrence, in: The Extreme Proterozoic: Geology, Geochemistry and Climate, edited by: Jenkins, G. S., AGU, Washington, DC, 107-124, 2004.

Peltier, W. R., Liu, Y., and Crowley, J. W.: Snowball Earth prevention by dissolved organic carbon remineralization, Nature, 450, 813-818, 2007.
Perovich, D. K.: The optical properties of sea ice, US Cold Reg. Res. Eng. Lab. Monogr., 96, 1-31, 1996.

Perovich, D. K., Grenfell, T. C., Light, B., and Hobbs, P. V.: Seasonal evolution of the albedo of multiyear Arctic sea ice, J. Geophys. Res., 107, 8044, doi:10.1029/2000JC000438, 2002.

Pierrehumbert, R. T., Abbot, D. S., Voigt, A., and Koll, D.: Climate of the Neoproterozoic, Annu. Rev. Earth Planet. Sci., 39, $417-$ 460, 2011.

Pollard, D. and Kasting, J. F.: Climate-ice sheet simulations of Neoproterozoic glaciation before and after collapse to Snowball Earth, in: The Extreme Proterozoic: Geology, Geochemistry, and Climate, Geophys. Monogr. Ser., edited by: Jenkins, G., AGU, Washington, DC, vol. 146, 91-105, 2004.

Pollard, D. and Kasting, J. F.: Snowball Earth: a thin-ice solution with flowing sea glaciers, J. Geophys. Res., 110, 010, doi:10.1029/2004JC002525, 2005.

Poulsen, C. J. and Jacob, R. L.: Factors that inhibit Snowball Earth simulation, Paleoceanography, 19, PA4021, doi:10.1029/2004PA001056, 2004.

Richter, J. H. and Rasch, P. J.: Effects of convective momentum transport on the atmospheric circulation in the community atmosphere model version 3, J. Climate, 21, 1487-1499, 2008.

Rothman, D. H., Hayes, J. M., and Summons, R. E.: Dynamics of the Neoproterozoic carbon cycle, P. Natl. Acad. Sci. USA, 100, 8124-8129, 2003.

Sellers, W. D.: A global climate model based on the energy balance of the Earth-atmosphere system, J. Appl. Meteorol., 8, 392-400, 1969.

Shields, C. A., Bailey, D. A., Danabasoglu, G., Jochum, M., Kiehl, J. T., Levis, S., and Park, S.: The low resolution CCSM4, J. Climate, doi:10.1175/JCLI-D-11-00260.1, in press, 2012.

Smith, R., Jones, P., Briegleb, B., Bryan, F., Donabasoglu, G., Dennis, J., Dukowicz, J., Eden, C., Fox-Kemper, B., Gent, P., Hecht, M., Jayne, S., Jochum, M., Large, W., Lindsay, K., Maltrud, M., Norton, N., Peacock, S., Vertenstein, M., and Yeager, S.: The Parallel Ocean Program (POP) reference manual: Ocean component of the Community Climate System Model (CCSM), Los Alamos National Laboratory Tech. Report, LAUR10-01853, 140 pp., 2010.

Vavrus, S. and Waliser, D.: An improved parameterization for simulating Arctic cloud amount in CCSM3 climate model, J. Climate, 21, 5673-5687, 2008.

Voigt, A. and Marotzke, J.: The transition from the present day climate to a modern Snowball Earth, Clim. Dynam., 35, 887-905, 2010.

Voigt, A., Abbot, D. S., Pierrehumbert, R. T., and Marotzke, J.: Initiation of a Marinoan Snowball Earth in a state-of-the-art atmosphere-ocean general circulation model, Clim. Past, 7, 249263, doi:10.5194/cp-7-249-2011, 2011.

Warren, S. G. and Brandt, R. E.: Comment on "Snowball Earth: A thin-ice solution with flowing sea glaciers" by David Pollard and James F. Kasting, J. Geophys. Res., 111, C09016, doi:10.1029/2005JC003411, 2006.

Warren, S. G., Brandt, R. E., Grenfell, T. C., and Mckay, C. P.: Snowball Earth: Ice thickness on the tropical ocean, J. Geophys. Res., 107, 3167, doi:10.1029/2001JC001123, 2002.

Williams, G. E.: Proterozoic (pre-Ediacaran) glaciation and the high obliquity, low-latitude ice, strong seasonality (HOLIST) hypothesis: principles and tests, Earth Sci. Rev., 87, 61-93, 2008. 
Wiscombe, W. J. and Warren, S. G.: A model for the spectral albedo of snow I. Pure snow, J. Atmos. Sci., 37, 2712-2733, 1980.

Yang, J., Peltier, W. R., and Hu, Y.: The initiation of modern "soft Snowball" and "hard Snowball" climates in CCSM3, Part I: the influence of solar luminosity, $\mathrm{CO}_{2}$ concentration and the seaice/snow albedo parameterization, J. Climate, 25, 2711-2736, 2012a.
Yang, J., Peltier, W. R., and Hu, Y.: The initiation of modern "soft Snowball" and "hard Snowball" climates in CCSM3, Part II: climate dynamic feedbacks, J. Climate, 25, 2737-2754, 2012b. 